\title{
Genetic variation in traits affecting sawn timber recovery in plantation-grown Eucalyptus nitens
}

\author{
David Paul Blackburn • Matthew G. Hamilton • \\ Chris E. Harwood • Trevor C. Innes • Bradley M. Potts • \\ Dean Williams
}

Received: 13 January 2011 / Accepted: 11 August 2011 /Published online: 31 August 2011

(C) INRA and Springer Science+Business Media B.V. 2011

\begin{abstract}
- Introduction There is increasing interest in managing Eucalyptus nitens plantations for sawn timber production.

- Aims This study aimed to determine the potential for genetic improvement of traits affecting green sawn board recovery in plantation-grown $E$. nitens.

- Methods The study was undertaken on an E. nitens progeny trial. All trees were measured for diameter at breast height $(\mathrm{DBH})$ and stem straightness, and 560 trees were selected for timber processing. Assessment was made of survival, log and green sawn board volume, log taper, and
\end{abstract}

Handling Editor: Barry Alan Gardiner

D. P. Blackburn · M. G. Hamilton • B. M. Potts

School of Plant Science, University of Tasmania,

Private Bag 55,

Hobart, Tasmania 7000, Australia

D. P. Blackburn $(\varangle) \cdot$ M. G. Hamilton • C. E. Harwood •

T. C. Innes $\cdot$ B. M. Potts $\cdot$ D. Williams

CRC for Forestry,

Private Bag 12,

Hobart, Tasmania 7001, Australia

e-mail: david.blackburn@crcforestry.com.au

C. E. Harwood

CSIRO Sustainable Ecosystems,

Private Bag 12,

Hobart, Tasmania 7001, Australia

T. C. Innes

Gunns Ltd.,

PO Box 572, Launceston, Tasmania 7250, Australia

D. Williams

Forestry Tasmania,

79 Melville Street,

Hobart, Tasmania 7000, Australia both upper and lower log end splitting. Genetic variation in and between these traits was estimated.

- Results Genetic differences among races were significant for DBH at years 9 and 14, stem straightness, log taper and green sawn board volume. Within-race, narrow-sense heritabilities were significant for DBH, stem straightness, log volume, and both upper and lower log end splitting. Positive and significant additive genetic correlations were observed between DBH at all ages and survival, stem straightness and log volume. Significant adverse genetic correlations were shown between upper log end splitting and DBH at years 9 and 14.

- Conclusion These findings showed that harvest-age stem straightness and log volume objective traits in E. nitens are amenable to genetic improvement and that selection for early-age DBH in breeding programmes should improve harvest-age survival, stem diameter and straightness, as well as log and green sawn board volume. However, these improvements are likely to be countered to some extent by increased end splitting of logs from larger trees.

Keywords Sawn-board $\cdot$ Recovery $\cdot$ Heritability $\cdot$ End splitting $\cdot$ Stem straightness

\section{Introduction}

In Australia, supplies of sawlogs from native eucalypt forests are declining, and the prospective role of eucalypt plantations for sawlog supply has received much attention. Whilst most eucalypt plantations are grown for pulpwood production, there is an increasing worldwide estate of eucalypt plantations grown for solid wood products, including structural timber for construction, and appearance-grade products such as profile mouldings, flooring, furniture and wall panelling (Donnelly et al. 2003). Small-diameter sawlogs 
from unthinned and unpruned plantations are generally not suitable for the production of appearance-grade sawn timber because of defects due to knots, low green board recoveries, poor durability and drying defects (Nolan et al. 2005). However, such logs can be processed for structural timber, finger-jointed products, and knotty appearance products or veneered for plywood laminates and reconstituted solid wood products such as laminated veneer lumber.

The past two decades have seen the rapid growth of the Australian eucalypt hardwood plantation estate, which in 2010 approached 1 million hectares (Bureau of Rural Sciences 2010). The Australian plantation estate of Eucalyptus nitens is approximately 200,000 ha, over $70 \%$ of which is located in Tasmania (Parsons et al. 2006). The species is favoured where low temperatures (Tibbits and Hodge 2003) or Mycosphaerella leaf disease (Mohammed et al. 2003) restrict the growth or survival of Eucalyptus globulus. Twenty-five thousand hectares of Tasmanian $E$. nitens plantations are now being grown under sawlog silvicultural regimes, and additional areas of sawlog plantations are under development by other companies.

Research has recently been undertaken on wood processing requirements and technologies for sawn wood production from plantation eucalypts (Washusen et al. 2009). One option to enhance economic performance is to improve tree, log and wood characteristics (traits) through breeding. Log diameter determines whether a log can be processed for solid timbre or is sent for alternative types of processing. This segregates the logs from a plantation into different production systems with dissimilar cost and revenue structures. Diameter also has a major bearing on the selection of sawing strategy and influences the proportions of back-sawn, quarter-sawn and mixed-sawn boards extracted from each log (Washusen and Innes 2008). In turn, the sawn-board type influences board characteristics such as drying defects and shrinkage, and hence board value. Increasing log diameter will generally result in a higher volume recovery of high-value select and standard grades as a proportion of log volume (Washusen and Innes 2008).

Stem straightness influences the length of acceptably straight sawlog that can be obtained, and in turn the volume of green boards (i.e. sawn timber prior to drying) recovered from the tree. There is typically a maximum permissible log sweep (deviation of the stem's longitudinal axis from a straight line), which largely depends on the sawing system employed to process the logs. Excessive sweep results in logs being processed for alternative products such as pulp. It is difficult, time-consuming and therefore expensive to directly measure the straightness of standing tree stems, making it unfeasible to physically measure stem straightness of all the trees in a large research trial or plantation. Therefore, visual assessment methods ranking trees into stem straightness categories have been widely adopted for the evaluation of stands prior to harvesting and for stem assessment in tree breeding trials (Macdonald et al. 2009).

Stem taper is the rate of decrease in stem diameter per unit length of stem. Taper may vary along the stem depending on tree, stand, site characteristics and silvicultural history (Larson 1963). For a given stem diameter at breast height, increasing $\log$ taper will reduce the recovery of green sawn boards.

Plantation-grown eucalypts are known to exhibit high levels of longitudinal growth stresses in the peripheral layers of the stem (Yang et al. 2001; McKenzie et al. 2003), the release of these growth stresses during tree felling, and crosscutting of logs can lead to a high incidence and severity of log end splitting (McKenzie et al. 2003; Valencia et al. 2011). Valencia et al. (2011) demonstrated that log end splitting was a significant predictor of green board end splitting in E. nitens, which affects the overall total green board volume recovery. In sawing small-diameter plantation eucalypts, multi-saw, single-pass linear sawing systems with chippers that first remove the outer peripheral wood have the advantage over single-saw systems by symmetrically releasing growth stresses during processing. This can reduce losses due to board deflection (e.g. bow and spring) and end splitting and therefore improve green sawn board recoveries (Washusen and Innes 2008; Washusen et al. 2009; Blakemore et al. 2010).

A breeding objective is a combination of biological traits that tree growers and/or timber processors wish to genetically improve for a particular end product (Borralho et al. 1993; Greaves et al. 1997). Whilst there has been extensive research on breeding E. nitens for the pulp and paper industry (Borralho et al. 1993; Greaves et al. 1997), breeding objectives for solid wood products and the associated potential for genetic improvement are less clear, particularly in the face of changing processing technologies and products (Kube et al. 2001; Raymond 2002). Determining which traits should be included in breeding objectives for solid wood products is the subject of ongoing research. Sawlog volume production will clearly affect the profitability of sawmilling enterprises and will be included in a solid wood breeding objective. Traits linked to green board recovery and value, such as wood strength, dimensional stability and appearance characteristics such as checking (Hamilton and Potts 2008; Blackburn et al. 2010) will also be relevant. Whilst relatively unimportant for pulpwood (Borralho et al. 1993; Greaves et al. 1997), tree architecture traits such as stem straightness, stem taper, frequency of forking and branch characteristics can also affect green board recovery and value.

In tree improvement programmes, breeders rarely wait until harvest age before selecting the most favourable genotypes for further breeding or deployment. A set of selection criteria is used (e.g. core wood basic density, tree diameter at breast height and stem straightness score), 
which are easily and cost-effectively measured at a young age (Ponzoni and Newman 1989; Hamilton et al. 2010). Ideally, these criteria are strongly genetically correlated with the harvest-age objective traits and therefore provide the tree breeder with information about traits in the breeding objective. To achieve gains in objective traits requires both the selection criteria and objective traits to be under genetic control (Falconer and Mackay 1997) and correlated with each other. Breeding for two or more traits simultaneously means tree breeders must gauge the strength, stability and direction (+/-) of the genetic correlations between selection criteria and all chosen objective traits (White et al. 2007).

The aim of this study was to estimate heritabilities and determine the strength of genetic correlations among selection age growth criteria and harvest-age objective traits that impact upon wood volume and green board volume recovered at processing of $E$. nitens. The commercial production system under study involved the sawing of logs from unpruned, unthinned $E$. nitens plantations into sawn boards for structural applications using a HewSaw ${ }^{\mathrm{TM}}$ R200 linear sawmill (Cannon and Innes 2008). We studied a 14-year-old E. nitens progeny trial established in 1993 to determine whether traits affecting green board volume recovery are under genetic control at the race and within-race (additive) level, and the extent to which early-age diameter at breast height $(\mathrm{DBH})$ is correlated with green board volume, harvest-age stem straightness, log acceptability for sawing and $\log$ end splitting.

\section{Materials and methods}

\subsection{Progeny trial}

This study was undertaken on an E. nitens base population progeny trial established near Tarraleah (latitude $42^{\circ} 18^{\prime} \mathrm{S}$, longitude $146^{\circ} 27^{\prime} \mathrm{E}$ ) in central Tasmania. The trial was established on a site $600 \mathrm{~m}$ above sea level with a mean annual rainfall of approximately $1,200 \mathrm{~mm}$. The trial comprised families derived from open-pollinated seed from 420 native forest parent trees sampled from 28 localities. Sampled localities extended over most of the natural range of $E$. nitens in the central highlands region of Victoria and encompassed three geographically and genetically distinct races: Southern, Northern and Connor's Plain (Hamilton et al. 2008). The trial was established as a randomised incomplete block design comprising six replicates, each of 21 incomplete blocks, containing 20 families represented by a five-tree row plot. Initial spacing was $4 \mathrm{~m}$ between rows and $2 \mathrm{~m}$ between trees within rows. Fertiliser (100 g of superphosphate and $125 \mathrm{~g}$ of 20:10:0 $\mathrm{N} / \mathrm{P} / \mathrm{K})$ was applied to each tree 3 months after planting. No thinning or pruning was undertaken in the trial.

\subsection{Tree assessment and selection}

At age 14 years, all surviving tree stems in three of the trial replicates scheduled for harvesting were measured for $\mathrm{DBH}_{14}$ using a diameter tape, and the survival of each tree was recorded as 1 -alive and 0 - dead. Diameter at breast height had previously been assessed on all surviving trees in the whole trial at ages $4\left(\mathrm{DBH}_{4}\right)$ and $9\left(\mathrm{DBH}_{9}\right)$ years. One of the three harvested replicates was not assessed at ages 4 and 9. Trees selected for the processing study had to meet a supply contract log size criteria of $15-\mathrm{cm}$ minimum small-end and 28-cm maximum large-end diameter under bark. Small-end diameter was estimated at a butt log length of $5.6 \mathrm{~m}$ using a log taper value derived from data supplied by Forest Enterprises Australia Ltd. The logs also had to have acceptable straightness, with $\log$ sweep $<20 \%$ of the small-end diameter.

The straightness score categories used in these trials were: 6 (no stem deviation visually apparent), 5 (deviation $1-25 \%$ of small-end diameter), 4 (deviation $26-50 \%$ of small-end diameter), 3 (deviation $51-75 \%$ of small-end diameter), 2 (deviation $76-100 \%$ of small-end diameter) and 1 (deviation $>100 \%$ of small-end diameter). These deviations were estimated visually to approximately $8-\mathrm{m}$ height of stem. The method allowed the identification of stems that satisfied contractual log supply sweep requirements, enabled a ranking of phenotypes present at this site and allowed the estimation of the coefficient of additive variation for this trait. This method was recently developed by Forestry Tasmania. Prior to full trial assessment, to establish consistency between assessors and confirm that correct estimates would be made, a random sample of 20 visually independently assessed scores were compared. It was determined that visual stem straightness scores of 5 and 6 would meet the log sweep requirement over the first $6 \mathrm{~m}$ of stem height.

As far as possible, selected trees from each family were chosen such that all three harvested replicates were represented and families had a minimum of four trees sawn. A total of 560 trees from 129 families were selected for sawing.

Selected trees were harvested, with an average stump height of $0.25 \mathrm{~m}$, and the butt $\log$ was cut from each felled tree and debarked. To reduce the incidence of log end splitting, log ends were reinforced with MiTek GS 16-gauge gang nail plates and coated with Dussek-Campbell log grease. Identities of the selected trees were maintained during harvesting and transport using a wooden identity plug glued into a hole drilled in the standing tree just above the bottom end of the log, as described by Blackburn et al. (2010). 


\subsection{Assessment of log end splitting and log taper}

At the sawmill, 50-mm disks with the gang nails attached were removed from both ends of each $\log$. The following day, log lengths and the largest and smallest diameters at each end were measured, and end splitting was assessed within an 8-h period using the Log Split Index Method 2 (Yang 2005). This method was chosen as it includes measurement of splits which extend to the log periphery and along its longitudinal surface. The method sums the estimated area of the log end split plane and divides the sum by the square of the log end radius, thus adjusting for $\log$ end diameter in the index value. Log taper was calculated as the difference between the small- and largeend $\log$ end radii divided by the log length, expressed as centimetres per metre of log length.

\subsection{Log processing and assessment of log} and green board volume

The harvested logs were processed by normal sawmill operations into structural timber for building and construction (Cannon and Innes 2008). At the sawmill log intake, optical scanning indicated that 64 logs exhibited excessive sweep, and these logs were rejected. Subsequent assessment of these logs showed that the log scanner was out of calibration and only 13 should have been rejected. The accepted logs were sawn with a R200 HewSaw ${ }^{\mathrm{TM}}$. This mill chips and saws small-diameter logs in a single pass, so peripheral growth stresses on opposite sides of the stem are released simultaneously, minimising deflection of green boards off the saw (Washusen and Innes 2008). Logs were batched into five size classes based on their small-end diameter, and for each diameter class, one cutting pattern was used to produce two, three, four, or six boards per log (Fig. 1 and Table 1). Visual grading of the boards (AS 2082 2000) into 'reject' or 'acceptable' classes was undertaken at mill operating speed within the confines of a restricted workspace; therefore, it was not possible to retain rejected boards for further assessment. For this reason, $100 \%$ green board recovery was assumed from the cutting pattern assigned to each log. The 'Frustum of a Cone' equation (Eshbach 1975) was used to calculate log volume. Board cutting pattern dimensions (Table 1) and individual log lengths were used to determine green board volumes per log.

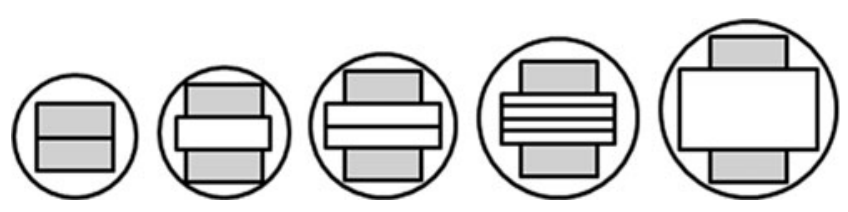

Fig. 1 Log cutting patterns (A-E). Cutting pattern board dimensions are in Table 1

\subsection{Statistical analyses}

For traits assessed on all trees within replicates (i.e. $\mathrm{DBH}_{4}$, $\mathrm{DBH}_{9}, \mathrm{DBH}_{14}$, stem straightness and survival), the following linear mixed model was fitted in ASReml 2.0 (Gilmour et al. 2006) to perform univariate restricted maximum likelihood analyses:

$$
\begin{aligned}
Y= & \text { MEAN }+\mathrm{REP}+\mathrm{RACE}+\operatorname{IBLOCK}(R E P) \\
& +\operatorname{PLOT}(I B L O C K)+\mathrm{FAMILY}(R A C E) \\
& +\operatorname{RESIDUAL}
\end{aligned}
$$

where $Y$ is the observation, MEAN is the mean, REP is the fixed replicate effect, RACE is the fixed race effect, IBLOCK (REP) is the random incomplete block within replicate effect, PLOT(IBLOCK) is the random plot within incomplete block effect, FAMILY(RACE) is the random family within-race effect and RESIDUAL is the residual. As trees selected for the sawn-board processing trial represented a small subset of the entire progeny trial, terms for IBLOCK(REP) and PLOT (IBLOCK) were omitted from the analysis of $\log$ and green board traits. For all traits under test, the residuals were observed to be approximately normally distributed.

To estimate genetic parameters for traits measured on selected trees only (i.e. $\mathrm{DBH}_{14}$ selected trees, log volume and $\log$ end split indices), a series of trivariate analyses were undertaken, including $\mathrm{DBH}_{14}$, stem straightness and the trait for which parameters were being estimated. Trivariate analyses were undertaken instead of univariate analyses in an effort to account for possible bias introduced through the selection of stems suitable for sawmilling. It was not possible to fit multivariate models including more than three traits due to convergence difficulties. The trivariate model included the same explanatory factors as the univariate model and allowed for covariation between random effects. However, plot and incomplete block terms were fitted for $\mathrm{DBH}_{14}$ and stem straightness only.

The additive variance $\left(\sigma_{\text {add }}^{2}\right)$, phenotypic variance $\left(\sigma_{\text {pheno }}^{2}\right)$, open-pollinated narrow-sense heritability $\left(h_{\mathrm{op}}^{2}\right)$ and percentage coefficient of additive variation $\left(\mathrm{CV}_{\text {add }}\right)$ were estimated for each trait as follows:

$\sigma_{\text {add }}^{2}=\frac{\sigma_{\text {fam }}^{2}}{r}$

$\sigma_{\text {pheno }}^{2}=\sigma_{\text {fam }}^{2}+\sigma_{\text {plot }}^{2}+\sigma_{\text {residual }}^{2}$

$h_{\mathrm{op}}^{2}=\frac{\sigma_{\mathrm{add}}^{2}}{\sigma_{\text {pheno }}^{2}}$

$\mathrm{CV}_{\text {add } \%}=100 \times \frac{\sqrt{\sigma_{\text {add }}^{2}}}{\bar{x}}$ 
Table 1 Log dimensions, number of logs processed, rankings of mean stem straightness, number of green boards extracted and their dimensions for each cutting pattern

\begin{tabular}{|c|c|c|c|c|c|}
\hline $\begin{array}{l}\text { Cutting } \\
\text { pattern }\end{array}$ & $\begin{array}{l}\text { No. of logs } \\
\text { processed }\end{array}$ & $\begin{array}{l}\text { Log small-end } \\
\text { diameter range }(\mathrm{cm})\end{array}$ & $\begin{array}{l}\text { Mean small-end } \\
\text { diameter }(\mathrm{cm})\end{array}$ & $\begin{array}{l}\text { Mean stem } \\
\text { straightness rank }\end{array}$ & $\begin{array}{l}\text { Green boards } \\
\text { recovered and } \\
\text { dimensions }(\mathrm{mm})\end{array}$ \\
\hline A & 17 & $15.0-16.9$ & 15.9 & 5.1 & 2 off, $106 \times 45$ \\
\hline B & 31 & $17.0-17.9$ & 17.5 & 5.4 & $\begin{array}{l}2 \text { off, } 106 \times 45 \\
1 \text { off, } 130 \times 45\end{array}$ \\
\hline $\mathrm{C}$ & 106 & $18.0-19.9$ & 18.9 & 5.6 & $\begin{array}{l}2 \text { off, } 106 \times 45 \\
2 \text { off, } 160 \times 30\end{array}$ \\
\hline D & 165 & $20.0-21.9$ & 20.9 & 5.5 & $\begin{array}{l}2 \text { off, } 106 \times 45 \\
4 \text { off, } 155 \times 17\end{array}$ \\
\hline $\mathrm{E}$ & 159 & $22.0-27.0$ & 24.9 & 5.7 & $\begin{array}{l}2 \text { off, } 106 \times 45 \\
1 \text { off } 190 \times 110\end{array}$ \\
\hline
\end{tabular}

where $\sigma_{\text {fam }}^{2}, \sigma_{\text {plot }}^{2}$ and $\sigma_{\text {residual }}^{2}$ are the variance components for FAMILY(RACE), PLOT(IBLOCK) and RESIDUAL, respectively, $r$ is the coefficient of relationship among individuals within open-pollinated families, set at 0.4 to account for an assumed selfing rate in open-pollinated families of $30 \%$ (Griffin and Cotterill 1988), and $\bar{x}$ is the mean. For traits assessed on the selected population, the plot term was not included in the mixed model, and thus their $\sigma_{\text {pheno }}^{2}$ did not include $\sigma_{\text {plot }}^{2}$. The significance of $\sigma_{\text {fam }}^{2}$ was tested using a 'one-tailed' likelihood ratio test (Self and Liang 1987). The variance components for survival were estimated using a binomial model with a probit link function (Gilmour et al. 2006), and the significance of $\sigma_{\text {fam }}^{2}$ was assessed using a $Z$ test. The significance of the fixed RACE term for each trait was gauged with a Wald $F$ test, where FAMILY(RACE) was the error term and the approximate denominator degrees of freedom were computed using the numerical derivatives method (Gilmour et al. 2006).

Bivariate analyses were undertaken to estimate pairwise covariances among random terms. Additive genetic correlations $\left(r_{\mathrm{a}}\right)$ were estimated according to the following function:

$r_{\mathrm{a}_{12}}=r_{\mathrm{fam}_{12}}=\frac{\sigma_{\mathrm{fam}_{12}}}{\sqrt{\sigma_{\mathrm{fam}_{1}}^{2} \sigma_{\mathrm{fam}}^{2}}}$

where $r_{\mathrm{fam}_{12}}$ is the FAMILY(RACE) correlation between traits 1 and 2, $\sigma_{\mathrm{fam}_{12}}$ is the FAMILY(RACE) covariance component between traits 1 and 2 , and $\sigma_{\text {fam }}^{2}$ and $\sigma_{\text {fam }}^{2}$ are the FAMILY(RACE) variances for traits 1 and 2, respectively. Significance tests of inter-trait genetic correlations against zero were conducted using a 'two-tailed' likelihood ratio test and against 1 or -1 , as appropriate, using a 'onetailed' likelihood ratio test (Gilmour et al. 2006). Inter-trait Pearson's correlation among phenotypic observations were estimated and two-tailed $t$ tests were used to test whether phenotypic correlations were significantly different from zero.
The significance of differences among the trait means for the five different cutting patterns was tested using a single factor fixed effect model fitted with the Proc Mixed procedure of SAS ${ }^{\mathrm{TM}}$ (version 9.1) and a Tukey-Kramer adjustment used for assessing the significance of pairwise comparisons.

\section{Results}

At the pre-harvest progeny trial assessment, approximately $86 \%$ of planted trees were surviving. Survival at earlier ages was not determined due to incomplete assessment of the trial. At age 14, there was no significant race difference in survival, but highly significant $(P<0.001)$ differences among races in $\mathrm{DBH}$ and stem straightness were evident (Table 2). There was no significant difference in $\mathrm{DBH}$ between races in the subset of 560 trees selected for sawing; however, there were significant differences in $10 \mathrm{~g}$ taper $(P<0.001)$, log volume $(P<0.05)$ and green board recovery $(P<0.01)$. No significant differences between races were detected in the end split index on the lower and upper logs. The Southern race clearly had the most favourable trait values for sawing. It had the greatest growth, greatest volume, least taper and straightest logs when compared with the mean values for the Northern and Connor's Plain races (Table 2).

In addition to race differences, all traits except log taper and green board recovery showed significant $(P<0.05)$ family and, thus, additive genetic variation within races (Table 2 ). Whilst survival differences were not evident between races, within races, the heritability at age 14 was 0.25 and highly significant. The $h_{\mathrm{op}}^{2}$ for $\mathrm{DBH}$ at different ages ranged from 0.17 to 0.20 and for tree stem straightness at age 14 years was 0.17 . For the subset of trees selected for sawing, the $h_{\mathrm{op}}^{2}$ for $\mathrm{DBH}$ was 0.33 , higher than that in the total trial population at the same age, and $h_{\text {op }}^{2}$ of log volume was 0.20 . Heritability 
Table 2 Race least-square means, $P$ values (to test the significance of race differences), overall trial mean, additive variance, narrow-sense heritability $\left(h_{\mathrm{op}}^{2}\right)$ and coefficient of additive variation $\left(\mathrm{CV}_{\mathrm{add}}\right)$ for studied traits (with standard errors shown in parenthesis)

\begin{tabular}{|c|c|c|c|c|c|c|c|c|}
\hline Trait & Southern & $\begin{array}{l}\text { Race mean } \\
\text { Northern }\end{array}$ & Connor's Plain & Race $P$ value & $\begin{array}{l}\text { Overall trail } \\
\text { mean }\end{array}$ & $\begin{array}{l}\text { Additive } \\
\text { variance }\end{array}$ & $h_{\mathrm{op}}^{2}$ & $\mathrm{CV}_{\text {add }}(\%)$ \\
\hline $\mathrm{DBH}_{4}(\mathrm{~cm})$ & $11.5(0.09)$ & $11.5(0.10)$ & $11.5(0.18)$ & ns & $11.5(0.09)$ & $0.62(0.08) * * *$ & $0.17(0.02)$ & 7 \\
\hline $\mathrm{DBH}_{9}(\mathrm{~cm})$ & $17.2(0.12)$ & $16.7(0.14)$ & $16.5(0.36)$ & $* *$ & $17.2(0.12)$ & $2.92(0.48) * * *$ & $0.20(0.02)$ & 10 \\
\hline $\mathrm{DBH}_{14}(\mathrm{~cm})$ & $21.5(0.18)$ & $20.3(0.16)$ & $19.6(0.31)$ & $* * *$ & $21.5(0.18)$ & $3.30(0.35) * * *$ & $0.19(0.03)$ & 9 \\
\hline $\begin{array}{l}\text { Survival binary } \\
1 \text {-alive } 0 \text { - dead }\end{array}$ & $0.86(0.01)$ & $0.87(0.01)$ & $0.86(0.02)$ & ns & $0.86(0.01)$ & $0.12(0.01) * * *$ & $0.25(0.03)$ & N/A \\
\hline Stem straightness & $4.3(0.05)$ & $4.0(0.05)$ & $3.7(0.08)$ & $* * *$ & $4.3(0.05)$ & $0.10(0.01) * * *$ & $0.17(0.02)$ & 8 \\
\hline $\mathrm{DBH}_{14}(\mathrm{~cm})$ selections & $26.9(0.14)$ & $26.9(0.32)$ & $26.4(0.63)$ & $\mathrm{ns}$ & $26.9(0.14)$ & $2.03(0.67) * * *$ & $0.33(0.10)$ & 5 \\
\hline Log taper $\left(\mathrm{cm} \mathrm{m}^{-1}\right)$ & $0.40(0.01)$ & $0.47(0.02)$ & $0.49(0.03)$ & $* * *$ & $0.40(0.01)$ & $0.003(0.00) \mathrm{ns}$ & $0.14(0.09)$ & 12 \\
\hline Log volume $\left(\mathrm{m}^{3}\right)$ & $0.250(0.00)$ & $0.232(0.00)$ & $0.223(0.01)$ & $*$ & $0.250(0.00)$ & $0.003(0.00) * * *$ & $0.20(0.11)$ & 23 \\
\hline Green board volume $\left(\mathrm{m}^{3}\right)$ & $0.122(0.00)$ & $0.113(0.00)$ & $0.099(0.01)$ & $* * *$ & $0.122(0.00)$ & $0.001(0.00) \mathrm{ns}$ & $0.17(0.03)$ & 25 \\
\hline $\begin{array}{l}\text { Lower log } \\
\text { End-split index }\end{array}$ & $0.72(0.04)$ & $0.70(0.09)$ & $0.58(0.17)$ & ns & $0.72(0.04)$ & $0.009(0.00) * *$ & $0.28(0.09)$ & 14 \\
\hline $\begin{array}{l}\text { Upper log } \\
\text { End-split index }\end{array}$ & $0.80(0.04)$ & $0.80(0.08)$ & $0.80(0.15)$ & ns & $0.80(0.04)$ & $0.013(0.00) * * *$ & $0.46(0.11)$ & 14 \\
\hline
\end{tabular}

ns not significant, $N / A$ not applicable

$* P<0.05, * * P<0.01, * * * P<0.001$

$\left(h_{\mathrm{op}}^{2}=0.46\right)$ for upper end splitting was the highest of all traits and was much greater than the corresponding value for lower end splitting $\left(h_{\mathrm{op}}^{2}=0.28\right)$. The coefficient of additive genetic variation for DBH of the selected trees $(5 \%)$ was approximately half that of the total population (Table 2).

Additive genetic correlations $\left(r_{\mathrm{a}}\right)$ among DBH at all ages assessed in the full progeny trial, as well as between all DBH measures and log volume, were strongly positive $\left(r_{\mathrm{a}}=\right.$ $0.83-1.01)$, highly significant $(P<0.001)$ and increased with age (Table 3). Genetic correlations between DBH and stem straightness were highly significant, positive and relatively stable for the three DBH ages $\left(r_{\mathrm{a}}=0.67-0.78\right)$. End splitting of the upper log was significantly, moderately and positively correlated with $\mathrm{DBH}_{14}$ at the genetic and phenotypic levels and with $\mathrm{DBH}_{9}$ at the genetic level (Table 3). The genetic and phenotypic correlations between upper and lower $\log$ end splitting were significant and positive ( $r_{\mathrm{a}}=0.55$ and $r=0.26$, respectively).

As diameter increased and the applied cutting patterns changed from A to E (Fig. 1 and Table 1), the percentage of green sawn board volume recovered from the log generally increased, as expected (Table 4). There was an approximately twofold increase in green board volume recovered between the smallest diameter range cutting pattern (A) and the patterns for the larger diameters (B-E). Pairwise comparison of log cutting pattern treatments showed that significant differences existed among levels of green board volume recovered in different diameter classes (Table 4), which demonstrated the important influence of log diameter on product recovery and hence on the economics of processing E. nitens plantation sawlogs. For the upper and lower log end split index, the larger cutting pattern classes generally differed significantly from one another, with more splitting occurring in logs cut with the E pattern.

\section{Discussion}

In this study, DBH heritability was relatively stable between early (4 years) and later ages ( 9 and 14 years), and additive genetic correlation estimates amongst all ages of DBH and between survival at age 14 years and early-age DBH were strongly positive and highly significant. This high correlation indicates that early-age DBH could be used to select for improved later-age survival and could also be an effective selection criterion for breeding to improve harvest-age DBH and the volume of timbre recovered per hectare. The estimates of narrow-sense heritabilities for DBH at all ages, survival and inter-age genetic correlations for DBH were similar to other published estimates for open-pollinated progeny trials of E. nitens (Hamilton and Potts 2008). These estimates were also comparable to those reported for the related temperate species E. globulus. For example, Stackpole et al. (2010) found similar positive genetic correlations between DBH and survival at age 16 years, whilst Chambers et al. (1996) also observed positive correlations between early-age DBH and survival in E. globulus.

Low heritability and coefficient of additive genetic variance for stem straightness indicated that it would be difficult to make rapid gains if selecting for this trait within races, although a significant between-race variation was 
observed and the more favourable mean value of the Southern race could be exploited. Our estimates of these genetic parameters were within the range of those previously reported for stem straightness in E. nitens (Hamilton and Potts 2008) and similar to studies in other eucalypt species (Arnold et al. 2004), but heritability was lower than that recently reported for E. globulus grown in Western Australia (Callister et al. 2011).

In this study, the relatively stable, strongly positive and highly significant additive genetic correlations between $\mathrm{DBH}$ at all ages and stem straightness indicated that early-age DBH could be used as a surrogate selection criterion to improve stem straightness in tree breeding programmes. It is possible that this strong correlation between stem straightness and DBH may, in part, have been an artefact of scoring stem straightness as a proportion of stem diameter. However, when individual phenotypic stem straightness scores were adjusted for tree diameter (based on simple linear regression parameter estimates derived from a model that fitted stem straightness as the response variable and DBH as the explanatory variable), strongly positive additive genetic correlations were still evident. This was indicative of a strong correlation between DBH and actual deviations from straightness. These findings support those of Hamilton and Potts' (2008) review of $E$. nitens genetic parameters, which also reported favourable average genetic correlations between DBH and stem straightness, and the study by Callister et al. (2011) in E globulus.

For all three races, the incidence of log end splitting was higher at the small end than the large end. This longitudinal trend has been previously observed in processing performance studies (Washusen et al. 2009; Valencia et al. 2011). Moderate heritabilities of both upper and lower log end splitting and a low to moderate coefficient of additive genetic variation indicate that these traits could be improved through breeding. The potential to reduce end splitting through breeding has also been demonstrated in Eucalyptus grandis by Telles dos Santos et al. (2004) who found moderate to high levels of heritability $\left(h^{2}=0.31\right)$ for $\log$ end splitting index. Inter-trait genetic correlations between upper log end splitting and all other traits assessed in the current study indicate that an unfavourable genetic relationship exists between diameter and log end splitting in E. nitens.

Log and board end splitting are difficult to predict in $E$. nitens as levels of peripheral growth stress, which is associated with splitting, are not closely correlated with any single growth parameter, but are influenced by a combination of factors that influence the tree at different ages and tree heights, depending on stand age and stocking (Biechele and Nutto 2008). In 22-year-old E. nitens trees, harvested from an unpedigreed plantation thinning trial in 
Table 4 Means of recovery traits for different log cutting patterns with standard errors shown in parenthesis

\begin{tabular}{llllllll}
\hline $\begin{array}{l}\text { Cutting } \\
\text { pattern }\end{array}$ & $\begin{array}{l}\text { Mean DBH } \\
(\mathrm{cm})\end{array}$ & $\begin{array}{l}\text { Mean log taper } \\
\left(\mathrm{cm} \mathrm{m}^{-1}\right)\end{array}$ & $\begin{array}{l}\text { Mean split index } \\
\text { lower log end }\end{array}$ & $\begin{array}{l}\text { Mean split index } \\
\text { upper log end }\end{array}$ & $\begin{array}{l}\text { Mean log } \\
\text { volume }\left(\mathrm{m}^{3}\right)\end{array}$ & $\begin{array}{l}\text { Green board } \\
\text { volume }\left(\mathrm{m}^{3}\right)\end{array}$ & $\begin{array}{l}\text { Green board } \\
\text { recovery }(\%)\end{array}$ \\
\hline $\mathrm{A}$ & $23.6(0.32) \mathrm{a}$ & $0.54(0.06) \mathrm{c}$ & $0.506(0.16) \mathrm{ab}$ & $0.776(0.16) \mathrm{ab}$ & $0.164(0.01) \mathrm{a}$ & $0.042(0.00) \mathrm{a}$ & 26.0 \\
$\mathrm{~B}$ & $24.0(0.24) \mathrm{a}$ & $0.46(0.02) \mathrm{b}$ & $0.750(0.12) \mathrm{ab}$ & $0.688(0.19) \mathrm{ab}$ & $0.181(0.00) \mathrm{b}$ & $0.085(0.00) \mathrm{b}$ & 46.7 \\
$\mathrm{C}$ & $25.0(0.14) \mathrm{b}$ & $0.37(0.01) \mathrm{ab}$ & $0.558(0.06) \mathrm{a}$ & $0.590(0.07) \mathrm{a}$ & $0.202(0.00) \mathrm{c}$ & $0.103(0.00) \mathrm{c}$ & 50.9 \\
$\mathrm{D}$ & $26.7(0.11) \mathrm{c}$ & $0.42(0.01) \mathrm{ab}$ & $0.689(0.05) \mathrm{ab}$ & $0.870(0.06) \mathrm{b}$ & $0.242(0.00) \mathrm{d}$ & $0.107(0.00) \mathrm{d}$ & 44.4 \\
$\mathrm{E}$ & $29.4(0.11) \mathrm{d}$ & $0.41(0.02) \mathrm{a}$ & $0.854(0.05) \mathrm{b}$ & $0.888(0.06) \mathrm{b}$ & $0.301(0.00) \mathrm{e}$ & $0.159(0.00) \mathrm{e}$ & 52.8 \\
\hline
\end{tabular}

Common letters indicate treatments that are not significantly different $(P<0.05)$, following a Tukey-Kramer adjustment for pairwise comparisons

Tasmania, end splitting was phenotypically positively correlated with DBH (Valencia et al. 2011), and this was also seen in this study. An earlier study in E. nitens showed $\log$ end splitting to be correlated to the percentage of heartwood, but not with log diameter (Purnell 1988). However, in the present study, although heartwood was not assessed, the correlation with DBH was low $(\leq 0.2)$, and there were only minor differences, albeit significant ones, in mean end-split scores across the five cutting patterns for both the lower and upper ends of the $\log$ (Table 4). Furthermore, because the trail processing was under normal sawmill operations, the relationship between the Log End Split Index-2 and the volume loss to board end splits could not be determined. A significant relationship has been demonstrated between this log split index and the volume of board lost to end docking in both E. globulus (Yang and Pongracic 2004) and E. nitens (Valencia et al. 2011). A positive genetic correlation between tree diameter and log end splitting index suggests that volume gains from breeding could be countered to some extent by subsequent volume losses through board splitting. This was demonstrated in a Tasmanian E. nitens sawn-board study where end docking of boards to remove end splitting was shown to produce a significant loss in merchantable green board volume, ranging from a $4.2 \%$ to a $9.5 \%$ percent loss in volume for quarter-sawn and back-sawn boards, respectively (Washusen et al. 2007).

\section{Conclusion}

This study showed that significant race and within-race genetic differences exist in harvest-age stem diameter and straightness as well as log volume in E. nitens, indicating that these traits are amendable to genetic improvement. Log taper and green board volume were shown to have significant genetic differences at the race level. Strongly positive genetic correlations among DBH at different ages and survival, and between DBH at year 4 and log volume, demonstrated that early-age DBH would be an effective selection criterion for breeding to improve harvest-age DBH and log and green-board volume recovery. However, significant adverse genetic correlations were observed between log end splitting and DBH at ages 9 and 14 years, indicating that selection for greater DBH may increase log end splitting. Favourable genetic correlations between DBH at all ages and stem straightness indicated that early-age DBH may potentially be used as a cost-effective surrogate selection trait to improve tree stem straightness in $E$. nitens breeding programmes.

Acknowledgements The study was supported by the Cooperative Research Centre for Forestry. We acknowledge the work of Dr Peter Volker in planning and establishing the progeny trial, which is part of a series of trials which underpins Forestry Tasmania's E. nitens tree breeding programme. We thank Dr. Greg Dutkowski for helpful advice on quantitative genetic analysis.

Funding We acknowledge substantial assistance from Forestry Tasmania, which provided trees from their progeny trial and personnel for straightness assessment, Forest Enterprises Australia Ltd. for processing the logs, and the Cooperative Research Centre for Forestry for David Paul Blackburn's PhD scholarship funding.

\section{References}

Arnold RJ, Johnson IG et al (2004) Genetic variation in growth, stem straightness and wood properties in Eucalyptus dunnii trial in Northern New South Wales. For Genet 11:1-12

AS 2082 (2000) Timber-hardwood-visually stress graded for structural purposes. Standards Australia, Homebush, NSW, p 51

Biechele T, Nutto L (2008) Growth stress in Eucalyptus nitens at different stages of development. Proccedings of the $51 \mathrm{st}$ International Convention of Society of Wood Science and Technology. November 10-12, Concepcion, Chile

Blackburn DP, Hamilton MG et al (2010) Stiffness and checking of Eucalyptus nitens sawn boards: genetic variation and potential for genetic improvement. Tree Genet Genomes 6:757-765

Blakemore P, Morrow A et al (2010) Plantation-grown Eucalyptus nitens: solid wood quality and processing performance on linear sawing systems with a range of commercial and experimental drying schedules. Technical Report 200. Cooperative Research Centre for Forestry, Hobart, Tasmania, Australia

Borralho NMG, Cotterill PP et al (1993) Breeding objectives for pulp production of Eucalyptus globulus under different industrial cost structures. Can J For Res 23:648-656 
Bureau of Rural Sciences (2010) Australia's Plantations 2010 Inventory Update. Department Agriculture, Fisheries and ForestryBureau of Rural Sciences, Canberra, Australia

Callister AN, England N et al (2011) Genetic analysis of Eucalyptus globulus diameter, straightness, branch size, and forking in Western Australia. Can J For Res 41:1333-1343

Cannon T, Innes T (2008) Markets for the wood products from nondurable hardwood sawlog plantations. Proceedings from a Joint Venture Agroforestry Program Conference: Plantation Eucalypts for High-Value Timber: Enhancing Investment Through Research and Development. Rural Industries Research and Development Corporation, Moorabin, Victoria, Australia, pp 110-125

Chambers PGS, Borralho NMG et al (1996) Genetic analysis of survival in Eucalyptus globulus ssp. globulus. Silvae Genetica 45:107-112

Donnelly R, Fynn R et al (2003) The global eucalyptus wood products industry - a progress report on achieving higher value utilisation. DANA Publishing Limited, New Zealand

Eshbach OW (1975) Handbook of engineering fundamentals. Wiley, New York

Falconer DS, Mackay TFC (1997) Introduction to quantitative genetics. Addison Wesley Longman, Harlow, Essex

Gilmour AR, Cullis BR et al (2006) ASREML 2.0. VSN International Ltd., Hemel Hempstead, UK

Greaves BL, Raymond CA et al (1997) Breeding objective for plantation eucalypts grown for production of kraft pulp. For Sci 43:465-472

Griffin AR, Cotterill PP (1988) Genetic variation in growth of outcrossed, selfed and open-pollinated progenies of Eucalyptus regnans and some implications for breeding strategy. Silvae Genetica 37:124-131

Hamilton MG, Potts BM (2008) Review of Eucalyptus nitens genetic parameters. N Z J For Sci 38:102-119

Hamilton MG, Joyce $\mathrm{K}$ et al (2008) Achievements in forest tree improvement in Australia and New Zealand 9. Genetic improvement of Eucalyptus nitens in Australia. Aust For 71:82-93

Hamilton M, Potts B et al (2010) Genetic correlations between pulpwood and solid-wood selection and objective traits in Eucalyptus globulus. Ann For Sci 67:1-10

Kube PD, Raymond CA et al (2001) Breeding Eucalyptus nitens to improve wood quality and profitablility. In: Developing the eucalypt of the Future. INFOR, Valdivia, Chile, p 99

Larson PR (1963) Stem form development of forest trees. Forest Science Monographs 5:1-42

Macdonald E, Mochan S et al (2009) Validation of a stem straightness scoring system for Sitka spruce (Picea sitchensis (Bong.) Carr). Forestry 82:419-429

McKenzie HM, Turner JCP et al (2003) Processing young plantationgrown Eucalyptus nitens for solid-wood products. 1: Individual-tree variation in quality and recovery of appearance-grade lumber and veneer. N Z J For Sci 33:62-78

Mohammed CL, Battaglia M et al (2003) Mycosphaerella leaf diseases of temperate eucalypts around the Southern Pacific rim. N Z J For Sci 33:362-372

Nolan G, Greaves B et al (2005) Eucalypt plantations for solid wood products in Australia - a review. 'If you don't prune it, we can't use it'. Forest \& Wood Products Research \& Development Corporation, Victoria, Australia

Parsons M, Gavran M et al (2006) Australia's Plantations 2006. Bureau of Rural Sciences Co.

Ponzoni RW, Newman S (1989) Developing breeding objectives for Australian beef cattle production. Anim Prod 49:35-47

Purnell RC (1988) Variation in wood properties of Eucalyptus nitens in a provenance trial on the Eastern Transvaal Highveld in South Africa. South African For J 144:10-22

Raymond C (2002) Genetics of Eucalyptus wood properties. Ann For Sci 59:525-531

Self SG, Liang KY (1987) Asymptotic properties of maximum likelihood estimators and likelihood ratio tests under nonstandard conditions. J Am Stat Soc 82:605-610

Stackpole DJ, Vaillancourt RE et al (2010) Age trends in genetic parameters for growth and wood density in Eucalyptus globulus. Tree Genet Genomes 6:179-193

Telles dos Santos EPT, Geraldi IO et al (2004) Estimates of genetic parameters of wood traits for sawn timber production in Eucalyptus grandis. Genet Mol Biol 27:567-573

Tibbits WN, Hodge GR (2003) Genetic parameters for cold hardiness in Eucalyptus nitens (Deane \& Maiden) Maiden. Silvae Genetica 52:89-97

Valencia J, Harwood C, Washusen R et al (2011) Longitudinal growth strain as a $\log$ and wood quality predictor for plantation-grown Eucalyptus nitens sawlogs. Wood Sci Technol 45:15-34

Washusen R, Innes T (2008) Processing plantation eucalypts for highvalue timber. Proceedings from a Joint Venture Agroforestry Program Conference: Plantation Eucalypts for High-Value Timber: Enhancing Investment Through Research and Development. Rural Industries Research and Development Corporation, Moorabin, Victoria, Australia, pp 92-109

Washusen R, Morrow A, Valencia JC et al (2007) Gould's Country Eucalyptus nitens thinning trial: solid wood quality and processing performance using conventional processing strategies. Technical Report 168. Cooperative Research Centre for Forestry, Hobart

Washusen R, Harwood CE et al (2009) Pruned plantation-grown Eucalyptus nitens: effects of thinning and conventional processing strategies on sawn board quality and recovery. N Z J For Sci 39:39-55

White TL, Adams WT, Neale D (2007) Forest genetics. CABI, Wallingford

Yang JL (2005) The impact of log-end splits and spring on sawn recovery of 32-year-old plantation Eucalyptus globulus Labill. Holz als Roh-und Werkstoff 63:442-448

Yang JL, Pongracic S (2004) The impact of growth stress on sawn distortion and log end splitting on 32-year-old plantation blue gum. Project no: PN03.1312 Forest and Wood Products Research Development Corporation, Melbourne, Australia, p 31

Yang JL, Fife D et al (2001) The effect of growth strain and other defects on the sawn timber quality of 10-year-old Eucalyptus globulus Labill. Aust For 65:31-37 